\title{
The Activity of the Kazan Governorate Nobility Self-Government in the Middle of the 19th - Early 20th Century
}

\author{
Ramil R. Khayrutdinov ${ }^{1} \&$ Yelena V. Mironova ${ }^{2}$ \\ ${ }^{1}$ Kazan (Volga Region) Federal University, Kazan, Russia \\ ${ }^{2}$ Institute of History named Sh.Mardzhani, Kazan, Russia \\ Correspondence: Ramil R. Khayrutdinov, Kazan (Volga Region) Federal University, 420008, Kazan, \\ Kremlyovskaya Street, 18, Russia. E-mail: ramilh64@mail.ru; Yelena.Mironova@yandex.ru
}

Received: June 2, 2015 Accepted: June 15, 2015 Online Published: June 29, 2015

doi:10.5539/jsd.v8n5p232 URL: http://dx.doi.org/10.5539/jsd.v8n5p232

\begin{abstract}
The importance of the research of the Kazan Governorate nobility self-government activity in the middle of the 19th - early 20th centuries is determined by the fact that the study of this issue gives the opportunity to define the scenarios of keeping the power in the hands of the nobility, as well as the domestic needs of the nobility who represented multifunctional institutions handling both the problems of their social class and the local administration issues. This research is supported by the system approach based upon the study of noble institutions as an integral whole, and all aspects of its activity are geared to the interests of the nobility. The article highlights the study of the Kazan Governorate noble institutions as the bodies of the social class self-government. The authors investigated the interaction with the local government, and the influence on the government policy during the petition campaign and by means of the meetings of the governorate noble society representatives. The activity of the noble institutions shows their role in the formation of the civil society. The practical value of the research is that its conceptual issues and conclusions may be used in the preparation of the summarizing and special works on the history of Russia and Tatarstan. These materials are of research and practical interest within the study of social, political and economic life of the Russian Empire and Kazan Governorate.
\end{abstract}

Keywords: Kazan Governorate, the second half of the 19th - early 20th centuries, the nobility self-government, the nobility

\section{Introduction}

The reactivation of the democratic, political, economic and social institutions in recent times led to the study of instances in the pre-revolutionary past of Russia. The epoch of "Great Reforms" of 60-70s of the 19th century, when the authorities and the society began to work more closely, creating new institutions of the civil society, is of special interest.

The example of the post-reform Kazan Governorate nobility organizations shows the effectiveness of the dialogue between the authorities and the society. At the beginning of the 1860s, the introduction of the noble institutions caused the withdrawal of some administrative functions, performing of which made the nobility corporation dependent on the governorate authorities. This led to the empowerment of nobles by birth in the realization of private and corporate social, economic and political interests. And the government, in their turn, tried to gain the support of the service class people during the periods which were crucial for them (Mironova, 2013).

Thus, the overwhelming defeat in the Crimean War of 1853-1856 demonstrated the necessity to refuse from the villeinage practice dominating in the country. The government, being in fear of the noble society's opposition to the planned reforms, gave them charge over the preparation and further realization of the Emancipation Reform. Despite the fact that the project was developed with the participation of the nobility, it failed to reconcile the contradicting views of the land-owning classes living in the regions with different economic conditions. As early as during the first year of the reform implementation, some assemblies of nobility became significantly more active. As a result, the detailed programs of reconsideration of the "Emancipation Manifesto of 19 February 1861" were worked out (Korelin, 1979). It concerns Tula, Petersburg and Moscow Governorates (Korelin, 1979). 
The government's intention to direct the mindset of the noble societies into the controlled course encouraged them to give the projects of some suggested changes to class assemblies, thus giving the nobility impulse to consider the problems connected with the realization of the Emancipation and local reforms. The Kazan nobility, who have carefully observed the processes taking place in the country up to here, also began to participate in the discussion of the projects of reforms (Mironova, 2013). In order to suppress the discussion of issues concerning the creation of the national representative body, the official authorities were quick to issue a range of decrees, reducing the freedom of nobility assemblies (and also district ones) to a specific range of problems with the aim of "diverting their attention of untimely and inconvenient claims concerning wide issues" (Chernukha, 1978). These actions of the government determined the kind of noble societies' activity during the two first post-reform decades, not going beyond the boundaries of one governorate. However, as early as from the beginning of 1880s, as affected by different factors in the work of noble self-governmental bodies, a new phase, characterized by the community of the governorate noble societies' power and the overall impact on the state policy, was marked out.

\section{Methodological Framework}

\subsection{The Research Objectives}

The aim of this research is to study the activity of the Kazan Governorate noble institutions in 1861-1917. It is important to consider the problems of interaction of the noble institutions with the governorate administration and the units of district self-government, with the aim to identify the significance of the nobility corporation in the system of local state administration. The study of forms of their interrelation with the central administration is of special interest for understanding the role of the nobility corporate body.

The study of the raised issues will give an opportunity to show the place and role of the noble institutions in the social, political, economic and cultural life of the province and country in the second half of the 19th - early 20th centuries.

\subsection{Theoretical and Methodological Basis of the Research}

The research is based upon the general scientific principles of learning (those of historicism and scientific objectivity) and concrete research methods subsequent upon them: historical-and-comparative and problematic-and-chronological methods, which let distinguish separate courses in the development of different aspects of the Kazan Governorate nobility self-government in the middle of the 19th - early 20th centuries. The method of systematization and classification gave the opportunity to retrace the evolution of the nobility organizations system, to create a holistic picture of their membership, functioning and role.

\subsection{Source Basis of the Research}

The following groups of sources made the source basis of the research: legislative acts, documents of management and record keeping, periodical press, memoirs, reference and statistic books. The legislative acts give the opportunity define the structure, membership and functions of the nobility organizations.

The documents of management and record keeping of the deputies', province and district assemblies, the secretariats of the province and district marshal of the nobility, the district nobility guardianship department are used in the article.

Besides, the materials of the local government (the documents of the Kazan governor's secretariat) and self-government (the bylaws of the Kazan Governorate district assembly) were studied.

The study of the Kazan Governorate periodicals (the newspapers "Kazanskiye Gubernskiye Vedomosti" ("The Kazan Governorate News"), "Volzhsky Vestnik" ("The Volga Messenger"), "Volzhsky Listok" (The Volga Sheet"), "Vecherneye Ekho" ("The Evening Echo"), "Kazansky Vecher" ("The Kazan Evening"), "Volzhsky Kurier" ("The Volga Courier") and "Zemskaya Nedelya" ("The Zemstvo Week") contributed to establishing the instances of the activity of the noble institutions.

The reference to the memoirs let broaden the idea of the Kazan nobility's participation in the class and district self-government, petition activity, and national meetings of the nobility (Kizevetter, 1996; Korsakov, 1898; Melnikov, 2002).

The authors of the article used the data of the official statistics, which are a base for retracing the dynamics of the land ownership and identifying the number of nobles who had the property qualification for participation in the nobility assembly (Pertsov et al., 1919).

The sources of the reference type include the "Pamyatnyie Knizhki" (Memorial Books) and Address Books, which give the opportunity to make a list of public servants in the noble institutions (Pinegin, 1900; Lyustritsky, 1890). 


\section{Results}

\subsection{The Activity of the Noble Institutions within the Local Administration in 1861-1917}

The early 1860s became an important turn in the activity of the governorate nobility societies - as a result of the Great Reforms they were released from the duty to elect the public servants to the local institutions. This fact coupled with the depriving the nobility of the monopoly on the land ownership give cause to say about the weakening of their role in the district administration. The reduction of the land ownership inevitably led to the decrease of the nobles' number, who had the property qualification and agreed to the voluntary work in the class self-government. Thus, in 1868 there were no candidates for the post of the permanent assessor of the Sviyazhsk police department and that of the member of the Chistopol nobility guardianship department. And in 1869-1877 there were no nobles who agreed to the unpaid post of deputy of the Cheboksary district nobility.

At the same time, the influence of the noble society, represented by the marshals of the nobility, increased. In particular, the elective posts existing before the reforms were replaced by new ones, but were still filled by the nobles, and, in some cases, by agreement with the district marshals of the nobility. The responsibility for the formation of the local peasant governmental bodies was imposed on them. They were assigned an active part at the introduction of zemstva. The marshals presided at the zemstvo meetings and numerous district tribunals (Mironov, 2000). This goes to prove that the government intended to turn the district marshals into the matter-of-fact heads of the district administration, which contributed to the strengthening of the positions of marshals in the region.

The creation of the local governmental bodies did not lead to the systematic cooperation with their nobility organizations. Nevertheless, the participation of the same representatives of the nobility corporation in the zemstrvo and noble institutions led to the cooperation in a range of issues, which gave the opportunity to mobilize the powers to solve some important problems, such as the development of the public health service, zemstvo school, the recovery from crisis in the agriculture, construction of the Moscow-Kazan railway, etc.

Under the influence of pecuniary burdens, the consideration of demands of the upper class representatives became the priority area in the work of the nobility assemblies. As a result, the nobility assemblies started active charity work - they worked out projects for economic support of the nobility, opened charities for the nobility, took measures to promote the education and upbringing of the nobility youth. Thus, the elderly and ill nobles were placed into specially established poorhouses; a hostel for the children of nobles with low income was opened, scholarships were introduced for them and money for transport was provided. Grants and pensions were paid to nobles who needed it. However, there existed the necessity to help a lot of nobles, which encouraged the Kazan nobility corporation to present an economic petition addressed to the Emperor and Ministers of Finance and Interior, and it was partially settled. At the same period, an issue about the creation of special funds with the financial participation of the state was raised. As a result, a Fund of Self-Help was established in the governorate.

The activity of the nobility organizations of this period had a peculiarity, which included the intensification of education, determined by the general cultural advance of the post-reform time. Besides, the status of Kazan as a scientific, educational and cultural centre, promoted it. For example, the outstanding people of national science worked in the nobility assembly: A.V. Vasilyev, D.A. Korsakov, A.N. Kazem-Bek, A.I. Yakobiy et al. The opening of the Archives of Arts and History in 1903 became the result of the educational activities of the nobility assemblies. Its funds contained the portraits of the marshals of the nobility, different household items, and a variety of written artifacts of the Kazan Region history.

\subsection{The Petition Activity of the Nobility Assembly of Kazan Governorate and Participation in the Nobility Organization}

In the late $1850 \mathrm{~s}$ - early $1860 \mathrm{~s}$, the nobility societies of the Russian Empire launched a petition campaign. It was predetermined by the preparation and implementation of the Emancipation, judicial and zestvo reform. The Kazan nobility did not show initiative in the discussion of projects of the reforms of the 1860 s, which were being prepared, and started to consider them only by authority of the government. Only from the beginning of $1880 \mathrm{~s}$, because of the pecuniary burdens, the Kazan governorate nobility organizations joined the petition campaign. During the meetings, the projects of providing financial aid to the nobles were worked out, and the economic petitions addressed to the Emperor and Ministers of Interior and Finance were made. These included claims for organizing the low-interest credit for land owners, the projects for introducing estate entails, some proposals for railways construction, etc.

The petition activity showed that the majority of the nobles aimed at adjusting to new conditions of the bourgeois development of the country with the help of the state. However, lack of unity in the noble society and 
inaptitude of the governorate noble societies to stand together made their fight for their material wealth ineffective. The government, in their turn, demonstrated their inaptitude to solve the nobility's problems quickly.

The Kazan nobility corporation became one of the initiators of creation of a national nobility organization in the late 19th - early 20th century. The introduction of such an association followed the meetings of the governorate marshals of the nobility (1865-1905). And in 1906 the founding congress of the United nobility took pace. The views of the Kazan Governorate noble institutions were represented by knyaz (prince) P. L. Ukhtomsky, S. S. Tolstoy-Miloslavsky, D. P. Artsybashev, V. V. Markovnilov and A. N. Boratynsky et al.

At the meetings of the Kazan governorate nobility assemblies, during the discussions of the resolutions of congresses, their views on a number of social, economic and political issues were formed. The Russo-Japanese War (1904-1905) and the Russian Revolution of 1905-1907 actualized the problem of representation of the people. The discussions highlighted the lack of unity in the nobility assembly; the adherents of different political ideologies, the representatives of liberal and right monarchial organizations participated in the debates. The acceptance of the need for the popular government introduction in accordance with the birth status, with granting the right of the discussion of draft laws and legislative initiative, became common. Due to the introduction of the State Duma, the agricultural issue began to be included into the agenda. The land owners were afraid of infringement of their financial interests, supposing that in the context of revolution, the Duma will make a decision to dissolve the private land ownership. In their opinion, the solution of the agricultural problem was possible by means of disintegration of the peasant community. The preliminary work on this issue was supposed to be handed over to the local commissions.

Thus, despite the increase of the reformatory intentions of the Kazan land-owning nobility, the proposals were quite moderate and did not call for drastic alterations in the existing political system.

During the participation of the Kazan nobility corporation in the activity of the nobility organization, they supported the reforms in the village and criticized the local reform project.

The following period in the participation of the Kazan corporation in the meetings of the United nobility (1909-1917) is characterized by lower activity. The initiatives of the Kazan nobility give place to considering the programs of the nationwide meetings and deputations' election. The problem of introducing the representatives of other classes into the membership of nobles became one of the basic issues of this period.

\section{Discussions}

The problem of the role of the nobility and their self-government in Russia appeared in the last third of the 18th century due to the formation of the nobility corporate organization and the increase of its role in the local government as a result of Catherine's reforms. During this period, the nobility produced from their ranks some ideologists who emphasized the really leading role of the service class people in the history of Russia and also proved their rights and achievements. The researchers specialized in the nobility - G. F. Miller (1790), M. M. Shcherbatov (1898) and M.G. Spiridov (1810) - became the authors of the first works on this theme. Such researchers as G. F. Miller and M. G. Spiridov focused on the nobility service and its meaning for the state. The role of the noble aristocracy in the state system was described in details by one of the prominent representatives of the nobility historiography and outstanding statesman M. M. Shcherbatov in his work "Istoriya Rossiyskaya s drevneyshikh vremyon" (The history of Russia from the earliest times") (Shcherbatov, 1898). The history of Russia was represented by M.M. Shcherbatov (1898) as the history of "autocracy", i.e. monocracy and the history of the nobilities' achievements. In his works, the author points out the fact that in the activity of the noble institutions created by Catherine II there were definite limits making them dependent on the local government.

In the first half of the $19^{\text {th }}$ century the researcher P.N. Gulyayev prepared the first works about the nobility class organizations (Gulyayev, 1831). They are descriptive and do not have the analysis of the role of the nobility organizations and the elective noble public servants in the local administration.

From the second half of the 19th century, due to the Great Reforms implementation, the researchers' interest in the history of the noble institutions increased. This theme was developed in the works of the "state school of thought" representatives in the Russian historiography - B. N. Chicherin (1862), K. D. Kavelin (1897), P. N. Milyukov (1904), A. D. Gradovsky (1904). The researches of B.N. Chicherin (1862) and K.D. Kavelin concerned the nobility public service conception. The main point of it was that, because of the disastrous lack of personnel, the government turned the service into the duty, thus enslaving the nobles. In the second half of the 18th century the nobility as an "exceptionally servant caste" came to is end (Kavelin, 1897; Chicherin, 1862). Nevertheless, the nobility continued to be of a servant character. The intention of the noble societies to govern the province corresponded to the state's demand in the recruitment for the governorate and district institutions created during the reign of Catherine II 
(Gradovsky, 1904). According to P.N. Milyukov, the nobility was "the dough used by the government to bake the civil servant" (Milyukov, 1904).

The history of the nobility self-government was touched upon in the works of V.O. Klyuchevsky, who distinguished the "emperor and nobles" period of the history of Russia (Klyuchevsky, 1983). He pointed out that the intention of the government to engage the nobility societies into the local administration corresponded to the nobles' interests who wanted to set up their supremacy in the regions by means of formation of the local government and court with the officials elected from their midst. Therefore, the formed noble institutions were dependent on the governor and vicegerents (Klyuchevsky, 1983).

During the "Great Reforms" time, there appeared complex researches on the history of the nobility and their class institutions (Korf, 1906; Poray-Koshits, 2003; Pavlov-Silvansky, 1898). During this period there was a problem of ineffectiveness of nobility organizations work in the system of local administration and lack of nobles' interest in the elective service. Some researchers explained this by the dependence of the nobility organizations on the governorate administration, thus developing the ideas of the predecessors about the weakening of the noble class' influence as a result of the reforms (Korf, 1906). The problem of defining the place of the nobility public institutions in the national administration was considered in the same vein in the works of the researchers of the late 19th - early 20th centuries (Lappo-Danilevsky, 1898; Grigoryev, 1910; Blinov, 1905, et al.).

At that time the journalism of the nobility appeared and it was represented by the historical feature stories by N. P. Semyonov (1899), A. D. Pazukhin (1886) et al. The representatives of this field pointed out the negative influence of the reforms of $1860-1870$ s on the nobility corporation and the decrease of its role in the local administration, thus developing the ideas of the predecessors about the weakening of the noble class' role as a result of reforms (Evreinov, 1905; Evreinov, 1898; Pazukhin, 1886; Semyonov, 1899; Polivanov, 1881).

During the Soviet period, because of the approval of the Marxist conception in the national historical studies, a change of approaches to the study of the problems of the nobility self-government took place, and the thesis that the reforms of the 18th-19th centuries were aimed at the nobility, became predominant. The recognition of the dominating role of the nobility and their social class institutions in the life of the country and regions was a typical characteristic in the Soviet historiography. The historical thought of the first half of the 20th century has an utterly tendentious character and does not give the opportunity to look objectively at the history of the upper class - it has a permanent cliché name of the "exploitative class", leading a "parasitic" mode of life. In the work on the political history of the country by M. S. Olminsky (1910) it was pointed out that the nobles neglected the elective service, because people of "low quality" became marshals, and "favour and benefits" predominated in the nobility assemblies (Olminsky, 1910). In the early 1940s, the academician Yu.V. Gauthier prepared a multivolume edition on the history of the regional administration in Russia, in which he considered the formation of noble institutions within the reforms of 1760-1770s (Gauthier, 1941). The author wrote that the local reform of 1775 was aimed at the nobility (Gauthier, 1941). A similar estimation of the governorate reform of Catherine II was also given in the subsequent works of Soviet historians (Pavlova-Silvanskaya, 1964).

The monograph by A. P. Korelin became the first fundamental research on the history of the noble class of the post-reform period (Korelin, 1979). It covers a wide range of issues, connected with the functioning of the nobility organization in 1861-1904.

Some aspects of the nobility organizations activity are described in the researches on the history of state institutions prepared by N. P. Eroshkin. The author writes about the reasons and conditions of formation of the nobility institutions, their role in the local administration and in the national nobility forums. According to N. P. Eroshkin, the nobility self-governmental bodies had the key role in the class affairs and in the general governorate administration (Eroshkin, 1983; Eroshkin, 1981), and during the post-reform period there was "almost a dominant influence in the district administration" (Eroshkin, 1983). Furthermore, the researcher considered that the nobility organization formed at the turn of the 19th and 20th centuries had a profound effect on the government policy (Eroshkin, 1975).

The problems of collaboration of the nobility corporations and autocracy in the post-reform period were covered in the works by Yu. B. Solovyev (1973; 1981; 1990), V. S. Dyakin (1978), V. G. Chernukha (1978). For example, Yu. B. Solovyev (1973) characterizes the policy concerning the noble society as a controversial one. On the one hand, the government aimed at consolidating the economic and political positions of the nobility. On the other hand, "the regime, in its essence, could not stand any organized power beside it. They saw not only support, but also a rival in the nobility".

The second half of the 1990s - early 2000s are marked by the active publication of works covering the history of the noble class and its social institutions. Such an interest is determined by the departure from the schemes 
widely used in the Soviet historiography and the intention to objectively represent the historical process.

An original view on the interaction of the nobility corporation and the authorities was presented by B. N. Mironov (Mironov, 2000), who called the 18th and 19th centuries the time of liberation of peasants "from the state serfdom". The researcher places the reforms of Catherine II and Alexander II on a par: the power was partially handed over to the provincial nobility in order to divert their attention, in the first case, of the palace revolution, in the second one of the big-league politics. In his opinion, the noble organizations "had the real opportunity to influence not only the governorate crown administration, but also the government" (Mironov, 2000). E. P. Barinova (2002; 2008) comes to the same conclusion, suggesting that the activity of the United nobility organization formed in the early 20th century had a significant impact on the work of the local authorities. According to L. E. Shepelev (2001), the supreme power, considering the noble society as a prospective oppositional political force, by means of law consciously preserved disunity within it.

G. V. Ibneyeva (2007) shows that as early as during the reign of Catherine II the mechanisms of the imperial power influence on the noble society began to be worked out.

The nobility service became the subject matter of such researchers as L. F. Pisarkova (2001), I. V. Faizova (1999). For example, L. F. Pisarkova (2001) refers to the facts testifying certain benefits of elective nobility service which stimulated the nobles' participation in the local administration. As a result, the elective representatives of the nobility participated, practically, in all the spheres of life of the Russian province (Pisarkova, 2001; Faizova, 1999). I.V. Faizova (1999) disproves the thesis that the nobility widely used the freedom of the obligatory service given in 1762, which was generally accepted in the national, mainly pre-revolutionary, historiography. She mentions a range of factors preventing mass dismissals of the nobles (Faizova, 1999).

The considerable interest in the history of the Russian nobility and its self-governmental bodies was expressed by international researchers. For example, modern historians V. V. Leontovich (1995), I. de Madariaga (2002), S. Bekker (2004) came to the conclusion that the nobility corporate organization was established for the sake of the interests of the state.

The development of the research methods adequate for the modern historical studies led to the formation of a new field in the national historiography based on the study of history taking into account its regional peculiarities. At the present stage, there are a lot of thesis works on the nobility's history, whose authors shared the opinion that the social class corporate organizations were formed so that the state could recruit the nobles for the local public service (Sizova, 1999; Shapovalov, 2002; Litvinova, 2008 et al.). The Manifesto on Freedoms of the Nobility of 1762 and the Charter to the nobility of 1785 became the means of influencing the motivation of nobles for public service (Marasinova, 2008). Considering the influence of the Great Reforms of 1960-1870s on the activity of the nobility organizations, the researchers came to the conclusion about the expansion of their competence in the zemstvo and urban life administration (Shevnina, 2003; Leshchenko, 2007 et al.).

The basis for the study of the history of the nobility self-government in post-reform Kazan Governorate was laid by the works of the researchers of the Middle and Lower Volga Regions - Yu. I. Smykov (1984), P. S. Kabytov (1982) et al.

The history of study of the nobility self-government in Kazan Governorate of the second half of the 19th - early 20th centuries is rather extensive. The Soviet and modern stages may be distinguished in it.

Separate subjects of history of the Kazan nobility organization were described in the works by G. N. Wulfson (Wulfson, 1950), who considered the activity of the Kazan Governorate Peasants' life Improvement Committee, and in those by E. V. Lipakov (Lipakov, 1989) who studied the history of the formation of the nobility corporation in the Kazan region of the 16th century. The thesis by O. A. Kurseyeva (Kurseyeva, 1984) became one of the first researches on the history of the noble class and its corporate institutions at the regional level. Referring to the serious source basis, the author considers in details the activity of the Middle Volga Region social class organizations of the late 19th - early 20th centuries, including those in Kazan. At the same time, the work has a biased nature, typical of the nobility historiography of the Soviet period.

The modern historiography of the Kazan Governorate nobility organizations is represented by the researches on the social and political life of the region (Khayrutdinov, 2002; Biktasheva, 2008; Nizamova, 2009; Aynutdinova, 2003; Chernyak, 2005; Alekseyev, 2001), by the works describing the life and activity of the most outstanding representatives of the nobility assemblies (Frolova, 1998), reference books (Dvoyenosova, 2001; Glukhov-Nogaybek, 2002 et al.).

In the late 1990s the articles covering the problems of the Tatar feudal nobles' integration into the membership of the nobility of Russia were published (Khayrutdinov, 1997; Dvoyenosova, 1997; Dvoyenosova, 1999). In the 
early 2000s the first publications about the Kazan Governorate nobility organizations appeared (Dvoyenosova, 2004; Vasilyeva, 2007).

The significant contribution into the study of the problems of the nobility self-government of the pre-reform Russia was made by S. A. Frolova $(2006 ; 2010)$. In her publications the author highlights the legal fundamentals of the functioning of the institution of the nobility marshals, considers the relationship of the nobility corporation heads with the governorate administration, and defines their role in the system of regional administration.

Bringing the historiographical review to a conclusion, it is important to point out that the theme of the noble class institutions is developed at the nationwide level. The monographs on the social policy and history of state institutions give the general characteristics of the activity of the nobility organizations of the late 18th - early 20th centuries; there are summarizing works on the noble class and elective service of the nobles. The historians of the pre-revolutionary period pointed out that the nobility institutions were completely dependent on the governorate administration. This gives evidence to conclude that the nobility organizations were not bodies of the social class self-government. Significant changes took place in the study of the history of the nobility organizations during the Soviet period. The researchers share their critical attitude to the nobility corporation and its institutions, the intention to emphasize the predominating position of the nobles as a social class, its dominance in the state and local administration. The study of the nobles' land ownership and problems of relationship of the nobility and autocracy became priority areas. The modern historiography of the nobility organizations is characterized by the pluralism in the assessment of their activity. The researchers are inclined to consider the governorate nobility self-governmental bodies as elements of the civil society.

The nobility institutions of Kazan Governorate of the first half of the 19th - early 20th century have not been the subject of an independent study, though some of them are studied in the publications mentioned above. Their activity is covered, to different extents, in the literature on the social and political life of the Kazan region, and also in the regional thesis works. Therefore, the representation of the activity, membership and role of the Kazan Governorate nobility organization during the post-reform period (1861-1917) remains relevant. The chronological framework of this research is limited by the time of the implementation of the Emancipation Reform of 1861, which initiated the beginning of the reorganization of the local administration system and the consequent evolution of the nobility institutions, and the time of completion of their activity in 1917.

\section{Conclusion}

The research carried out in accordance with its aims and objectives gives the opportunity to formulate the following conclusions.

1. The formation of the Kazan Governorate nobility organizations took place within the framework of the nationwide policy of local administration system. The example of Kazan Governorate shows that the goal to recruit the representatives of the noble class for the service in the administrative and judicial institutions set by the government was not completely achieved. The paucity of nobles caused difficulties in the recruitment for local judicial and administrative institutions.

2. The Great Reforms of the early 1860s influenced the role of the nobility assemblies in the formation of the local administration, the significance of the nobility marshals' institution, and on the impact of the nobility self-governmental bodies in general on the social, political and economic life of districts and the governorate. The reorganization of the local administration system led to the changes in the administrative activity of the nobility organizations. During the post-reform period, the number of civil servants, elected by the nobility assemblies for the local institutions, decreased. At the same time, the role of the district marshals of the nobility increased, and they became the members of the governorate assembly and the chairmen of the district zemstvo assemblies. Moreover, there was the interaction of the nobility institutions with the local self-governmental bodies in solving the problems of different social groups, in particular the problems of public education, construction of the Moscow-Kazan railway, collaborative charity during the Russo-Japanese War (1904-1905).

3. The retargeting on the solution of the social class problems, mainly economical ones, which appeared after the Emancipation Reform, was typical of the activity of the Kazan Governorate nobility institutions of the post-reform time. The studied period was the time of active charity, cultural and educational activity - a network of charitable institutions was organized, a system of loan, pension and subsidy granting was set; a charity school and scholarships for the noble youth were established; the Archives of Arts and History were opened. These events increased the importance of the Kazan Governorate nobility institutions in the eyes of the nobles by birth, promoted their consolidation, and preservation of the social class unity.

4. During the post-reform period, the nobility institutions began to be used actively by the Kazan Governorate 
nobles for influencing the social and economic policy of the state. However, these measures were ineffective, which is determined by the lack of unity within both the Kazan nobility corporation and the noble societies, and also by the government's inaptitude to solve the nobles' problems quickly.

At the same time, the participation of the Kazan governorate nobility institutions in the petition campaign in 1881-1902 demonstrated the possibility of having a dialogue with the authorities. During this period the basis for the formation of the nationwide nobility organization was laid for further collaboration with the autocracy.

5. The nobility institutions of Kazan Governorate directly participated in the formation and activity of the nationwide nobility organization. The work of the authorized Kazan nobles in the nationwide nobility forums, discussions of the decisions made at the meetings of the United nobility promoted the development of the social, economic and politic program of preserving the privileged position of the noble class. In general, the activity of the Kazan noble society in the nationwide nobility organization of the early 20th century is characterized, firstly, as aimed at the nobility, and, secondly, as pro-government one. The reason of such an orientation of the activity of the Kazan nobility assemblies is the predominance of the noble traditionalists in them, who, despite the significant decline in their financial situation as a result of reduction of their land ownership, continued to identify themselves with the power, and wanted to preserve the old social and political situation in the country. The participation of the Kazan Governorate nobility organizations in the work of the United nobility gave the opportunity to fight for the social, economic and political interests of the noble class together with the noble societies of other governorates.

\section{Recommendations}

The practical value of the research is that its conceptual issues and conclusions may be used in the preparation of the summarizing and special works on the history of Russia and Tatarstan. These materials are of research and practical interest within the study of social and political life of the Russian Empire and Kazan Governorate.

\section{Acknowledgments}

This work was funded by the subsidy allocated to Kazan Federal University for the state assignment in the sphere of scientific activities.

\section{References}

Alekseyev, I. E. (2001). The Black Hundreds in Kazan Governorate. Kazan.

Apukhtin, V. R. (1912). The Kazan noble people's militia. A sketch and materials about the formation, movements and military operations of the Kazan and Vyatka military force and the donations of the Kazan nobility during the Patriotic War. Moscow.

Aynutdinova, L. M. (2003). The liberal movement in Kazan Governorate (1900-1917). Kazan.

Barinova, E. P. (2002). The power and the land owning nobility of Russia of the early 20th century. Samara.

Barinova, E. P. (2008). The nobility of Russia in the early 20th century. The economic status and sociocultural image. Moscow.

Bekker, S. (2004). The myths about the Russian nobility: the nobility and privileges of the last period of Imperial Russia. Moscow.

Biktasheva, A. N. (2008). The Kazan governors in the dialogues of authorities (the first half of the 19th century). Kazan.

Blinov, I. (1905). The governors. The historical and juridical sketch. Saint-Petersburg.

Burdin, E. (2005). The noble family of the Molostovs. The Echo of Centuries, 1(39), 131-135.

Chernukha, V. G. (1978). The domestic policy of Tsarist autocracy from the middle of the 50s to the early 80s of the 19th century. Leningrad.

Chernyak, E. V. (2005). The zemstvo self-government in Russia (the instance of Kazan Governorate), 1864 March, 1918.

Chicherin, V. N. (1862). Some urgent issues. Moscow.

Dvoyenosova, G. A. (1997). The Tatar nobility of Kazan Governorate. The Echo of Centuries, 1, 39-53.

Dvoyenosova, G. A. (1999). The Tatar nobility. The Echo of Centuries, 1-2, 26-32.

Dvoyenosova, G. A. (2001). The Kazan nobility, 1785-1917: genealogical dictionary. Kazan.

Dvoyenosova, G. A. (2004). The Red Book of the nobility of Kazan Governorate of 1785-1917: reconstruction and historiographic analysis. Kazan. 
Dyakin, V. S. (1978). The autocracy, bourgeoisie and nobility in 1907-1911. Leningrad.

Ermolayev, I. P. (1982). The Middle Volga Region in the second half of the 17th-18th centuries: the governing of the Kazan region. Kazan.

Eroshkin, N. P. (1975). The autocracy on the eve of the failure. Teacher's Book. Moscow.

Eroshkin, N. P. (1981). The serfdom autocracy and its political institutions: (The first half of the 19th century). Moscow.

Eroshkin, N. P. (1983). The history of the state institutions of pre-revolutionary Russia. Moscow.

Evreinov, G. A. (1898). The past and preasant meaning of the Russian nobility. Saint-Petersburg.

Evreinov, G. A. (1905). The reform of the supreme state institutions of Russia and the representation of the people. Saint-Petersburg.

Faizova, I. V. (1999). The "Emancipation Manifesto" and the nobles'service in the 18th century. Moscow.

Frolova, S. A. (1998). The Kazan branch of the noble family of Molostvovs (the second half of the 18th century1861). (Unpublished master's thesis). Kazan.

Frolova, S. A. (2006). The power, nobility and private education in the Russian province in the first quarter of the 19th century. News of Higher Schools. The Volga Region. Series "Humanities", 3, 16-27.

Frolova, S. A. (2010). The nobility self-government in the provincial Russia in the late 18 th - the first half of the 19th centuries (the experience of Kazan Governorate): problems, previous researches. The history of Russia and Tatarstan: the results and prospects of the encyclopedic researches, 2, 21-27.

Gauthier, Yu. V. (1941). The history of the regional administration in Russia from Peter I to Catherine II (Vol. 2). Moscow-Leningrad.

Glukhov-Nogaibek, M. S. (2002). The retro vocabulary of Kazan: The first record of the geological, biographic, historic and regional encyclopedia. Kazan.

Gradovskiy, A. D. (1904). The basics of the Russian constitutional law (Collected ed., Vol. 9, Part III: The local self-governmental bodies). Saint-Petersburg.

Grigoryev, V. A. (1910). The reform of the local administration during the reign of Catherine II (The Manifesto on the Governorates of 7 November 1775). Saint-Petersburg.

Gulyayev, P. N. (1831). About the elections of the nobles and merchants for the post according to the existing laws and ceremonies. Saint-Petersburg.

Ibneyeva, G.V. (2007). The formation of the empire policy of Russia in the second half of the 18th century: the experience of political interaction. Kazan.

Kabytov, P. S. (1982). The agricultural relationship in the Volga Region in the period of imperialism (1900-1917). Saratov.

Kavelin, K. D. (1897). Collected edition Vol. 1. Saint-Petersburg.

Khayrutdinov, R. R. (1997). The Tatar feudal nobility and the Russian nobility: the problem of integration at the turn of the 18th - 19th centuries. Islam in the Tatar World: Materials of the International Symposium.

Khayrutdinov, R. R. (2002). The administration of the state village of Kazan Governorate. The late 18th - the first third of the 19th centuries. Kazan.

Kizevetter, A. A. (1910). The Local self-government in Russia. 9th-19th centuries. The historical sketch. Moscow.

Kizevetter, A. A. (1996). At the turn of two centuries: The memoirs of 1881-1914. Moscow.

Klyuchevsky, V. O. (1983). Unpublished works. Moscow.

Korelin, A. P. (1979). The nobility in the post-reform Russia. 1861-1904. Membership, number, corporate organization. Moscow.

Korf, S. A. (1906). The nobility and its social class administration for a century (1762-1855). Saint-Petersburg.

Korsakov, D. A. (1898). The past from the Kazan life of 1856-1860. D.A. Korsakov's memoirs about the past. Kazan.

Kurseyeva, O. A. (1984). The land-owning nobles of the Volga Region in the late 19th - early 20th century. 
(Unpublished master's thesis). Kuybyshev.

Lappo-Danilevsky, A. (1898). The sketch of the domestic policy of Empress Catherine II. Saint-Petersburg.

Leontovich, V. V. (1995). The history of liberalism in Russia. 1762-1914. Moscow.

Leshchenko, I. N. (2007). The nobility by birth in the context of post-reform Russia: by the materials of Tver Governorate (Unpublished master's thesis). Moscow.

Lipakov, E. V. (1989). The nobility of the Kazan region in the late 16th - first half of the 17th centuries. Formation. Membership. Service (Unpublished master's thesis). Kazan.

Litvinova, T. N. (2008). The organization and activity of the noble class institutions of Voronezh Governorate of the last quarter of the 18th - the first half of the 19th centuries (Unpublished master's thesis). Voronezh.

Lyustritsky, V. (1862). The Memorial Book of Kazan Governorate in 1861 and 1862. Kazan.

Madariaga, I. (2002). Russia during the reign of Catherine the Great. Moscow.

Marasinova, E. I. (2008). The ideological influence of the autocratic policy on the consciousness of the Russian nobility elite of the second half of the 18th century: by the materials of legislation and correspondence. Moscow.

Melnikov, N. A. (2002). 19 years of zevstvo service (1898-1916). The Star, 7, 117-153.

Miller, G. F. (1790). The news of the Russian nobles. Saint-Petersburg.

Milyukov, P. N. (1904). Sketches on the history of the Russian culture. The population, economic, state and social regime. Saint-Petersburg.

Mironov, B. N. (2000). The social history of Russia of the imperial period (the 18th-early 20th century): the genesis of the personality, democratic family, civil society and constitutional state (Vol. 1). Saint-Petersburg.

Mironova, E. V. (2013). The interaction of the supreme power with the regional community in Kazan Governorate. The spiritual life of the regional communities: history, traditions, modernity, 1, 173-176.

Nizamova, M. S. (2009). Zemstva of the Volga Region and the Urals (1864-1914): the social and economic aspect. Kazan.

Olminsky, M. S. (1910). The state, bureaucracy and absolutism in the history of Russia. Saint-Petersburg.

Pavlova-Silvanskaya, M. P. (1964). "The Manifesto on the Governorates" of the 7 November 1775) and its class essence (Unpublished master's thesis). Moscow.

Pavlov-Silvanskiy, N. P. (1898). The monarchic service class people. The origin of the Russian nobility. Saint-Petersburg.

Pazukhin, A. D. (1886). The modern state of Russia and the social class issue. Moscow.

Pertsov, V. V. (1919). The statistical and economic sketches of Kazan Governorate. Kazan.

Pinegin, M. N. (1900). The address book of Kazan Governorate of 1900. Kazan.

Pisarkova, L. F. (2001). The development of the local self-government in Russia before the Great Reforms: the custom, duty, and right. The national history, 3, 31 .

Polivanov, M. K. (1881). About the role and rights of the Russian nobility: (The thoughts and notes about one conversation). Vladimir.

Poray-Koshits, I. A. (2003). The history of the Russian nobility from the 9th to the late 18th centuries. Moscow.

Semyonov, N. P. (1899). Our nobility: Its position before and after the reform. Saint-Petersburg.

Shapovalov, V. A. (2002). The nobility of the Central Black Earth Region of Russia during the post-reform period (Unpublished master's thesis). Moscow.

Shcherbatov, M. M. (1898). The history of Russia from the earliest times. Essays. Vol. 2. Saint-Petersburg.

Shepelev, L. E. (2001). The bureaucratic world of Russia. The 18th - early 20th century. Saint-Petersburg.

Shevnina, O. E. (2003). The image of the provincial nobility in the late 1850s-1870s: by the materials of the Volga Region governorates. (Unpublished master's thesis). Penza.

Sizova, O. V. (1999). The nobility of Yaroslavl Governorate in the late 18th - early 20th centuries. (Unpublished master's thesis). Yaroslavl. 
Smykov, Yu. I. (1984). The peasants of the Middle Volga Region during the capitalism period: social and economic research. Moscow.

Solovyev, Yu. B. (1973). The autocracy and nobility in the late 19th century. Leningrad.

Solovyev, Yu. B. (1978). The autocracy and nobility in 1907-1914. Leningrad.

Solovyev, Yu. B. (1981). The autocracy and nobility in 1902-1907. Leningrad.

Spiridov, M. G. (1810). The short description of the Russian nobles'services. Moscow.

Vasilyeva, I. V. (2007). The activity of the nobility guardianship departments in the Kazan and Simbirsk Governorates in the 18th century. Bulletin of Chuvash University, 1, 3-10.

Wulfson, G. N. (1950). The struggle around the reform of 1861 in Kazan Governorate (1857 - spring of 1861). (Unpublished master's thesis). Moscow.

\section{Copyrights}

Copyright for this article is retained by the author(s), with first publication rights granted to the journal.

This is an open-access article distributed under the terms and conditions of the Creative Commons Attribution license (http://creativecommons.org/licenses/by/3.0/). 